
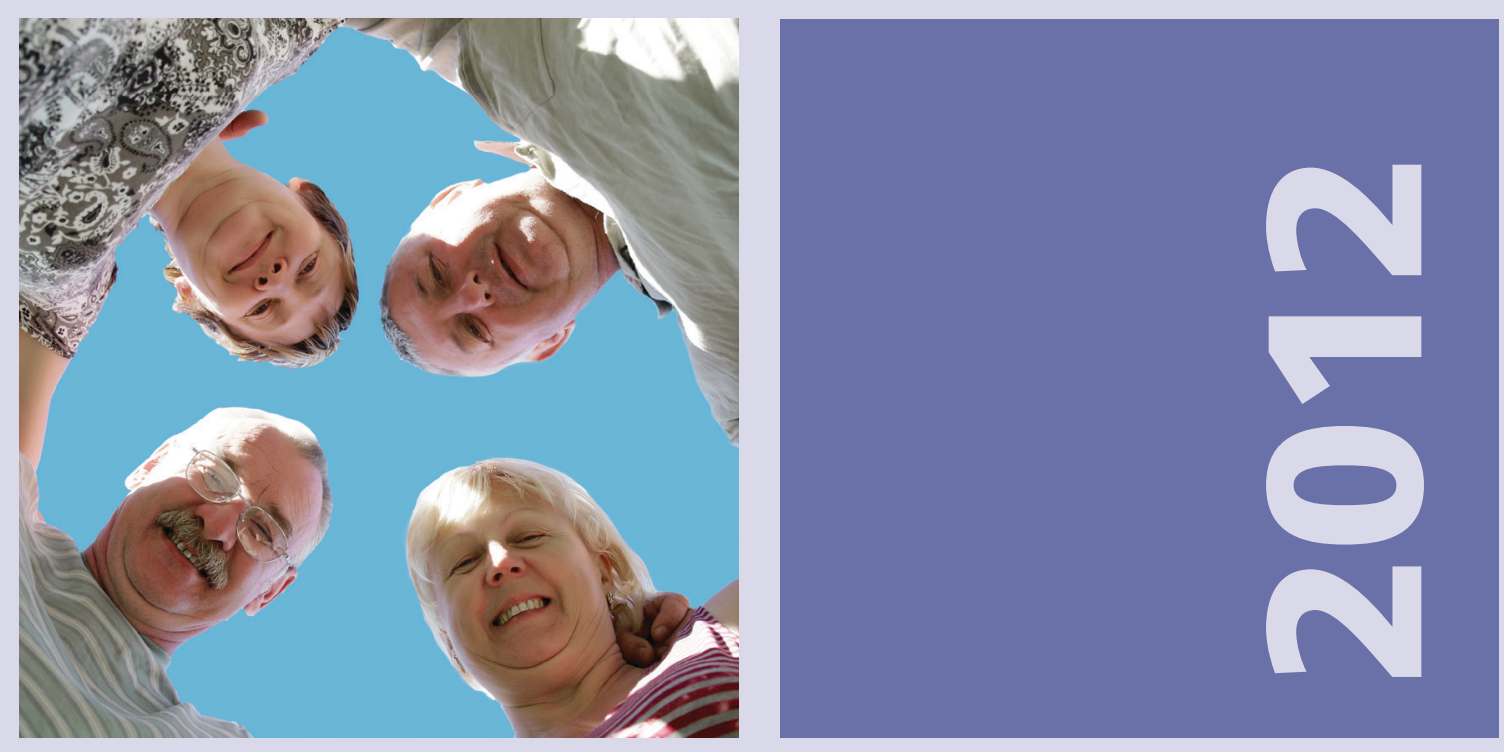

\title{
Supplementary Pensions and the Income of Ireland's Retirees
}

\section{tilda \\ Staidéar Fadaimseartha na hÉireann um Dhul in Aois}




\section{An Roinn Sláinte}

DEPARTMENT OF HEALTH

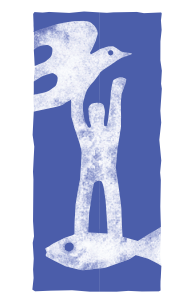

The

\section{A T L A N T I C Philanthropies}

Irish Life

Copyright @ The Irish Longitudinal Study on Ageing 2012

The Irish Longitudinal Study on Ageing

Lincoln Place

Trinity College Dublin

Dublin 2

Tel.: +35318964120

Email: tilda@tcd.ie

Website: www.tilda.ie

ISBN: 978-1-907894-03-9

https://www.doi.org/10.38018/TildaRe.2012-01 


\title{
Supplementary Pensions and the Income of Ireland's Retirees
}

Sanna Nivakoski and Alan Barrett

TILDA

and

Department of Economics, Trinity College Dublin

November 2012

\begin{abstract}
The objective of this report is to explore (a) the incomes of retirees in Ireland and (b) the distribution of supplementary pensions among them, although clearly there is a close relationship between (a) and (b). Our focus is on retirees and not on the full population of those aged 65 and over. For this reason, the analysis focuses on (a) men who are now retired but who have worked for at least fifteen years and (b) women who are now retired but who have worked for at least ten years. We find that the average income of male retirees is 58 per cent higher than that of female retirees. Much of this difference is driven by the fact that about half of the male retirees have supplementary pension compared to about a third of female retirees. In the case of both genders, factors such as education and having been a public sector worker are associated with having supplementary pensions. Career continuity matters for both genders too but in slightly different ways. For men, longer tenure with the same employer is important in determining the access to a supplementary pension but for women total work experience across all employers matters. The analysis suggests that any universal cut in the State pension would be regressive because the incomes of lower income groups would be disproportionately reduced.
\end{abstract}





\section{Contents}

1. Introduction

2. Background and motivation 3

3. Data and descriptive statistics 9

4. Analysing the distribution of supplementary pension coverage 17

5. Conclusions and implications 25

$\begin{array}{lr}\text { References } & 27\end{array}$ 


\section{Introduction}

Ireland's pensions system can be characterised in broad terms as comprising of three pillars. The first pillar is the social welfare element, with both contributory and noncontributory State pensions. The second pillar is made up of occupational pensions. The third pillar is made up of private pensions and other forms of saving. In addition to these three pillars, the system is impacted upon by the State through the taxation and regulatory systems.

Given this background of a relatively complex set of potential sources of pension incomes for Ireland's retirees, a number of questions arise. For example, what are the relative magnitudes of these various sources of pension income for existing retirees? How do the relative magnitudes differ across groups? In the context of this complex system and the many questions which arise, the aims of this paper are as follows. First, we provide descriptive information on the sources of pension incomes, both at an aggregate level and within certain subgroups. As will be seen, the striking finding to emerge from the descriptive analysis is the critical role played by supplementary pensions in determining the patterns of income across retirees. This gives rise to our second main aim which is to analyse the determinants of supplementary pension coverage among the retirees. We look at two broad sets of variables in this context the characteristics of the individual retirees and the characteristics of the jobs that they previously held. Variables of both types appear to matter.

We should stress at this point that our aims in this paper relate to retirees, by which we mean people who have participated in work during their lifetimes. Our focus is not on older people generally or on the distribution of income across older households. Our interest is in understanding how the pension system has operated for those who have worked. For this reason, we only examine the incomes of those who describe themselves as being retired and who report having worked at least 15 years in the case of men and 10 years in the case of women.

The paper is structured as follows. In Section 2, we provide some background along a number of dimensions. First (2.1), we discuss some international and Irish developments in pension policy. We then describe the Irish pension system and the specific features of it that motivate the approach taken in this research (2.2). Next, we present some theoretical considerations so that our empirical approach is better understood, in particular our focus on both individual and job characteristics in explaining supplementary pension coverage (2.3). We move on to summarise existing 
international and Irish literature related to this research, and outline the contribution made by this paper (2.4).

In Section 3 we describe The Irish Longitudinal Study on Ageing (TILDA) data which is used in the empirical analysis, and present descriptive tables and graphs on Irish retiree incomes, the importance of different pension income sources, and the levels and components of retirement incomes for different sub-groups of the retired population. In Section 4 we present the findings from the regression analyses on the incidence of supplementary pensions. In Section 5 , we review the findings and offer some policy-related conclusions. 


\section{Background and motivation}

\subsection{International and Irish developments in pension policy}

The issue of population ageing and the consequent pressures which this implies for pensions systems throughout the developed world is increasingly well-known and well understood. A World Bank (1994) report on demographic change and the challenges in providing financial security for retirees played an important role in the policy debate about future pension provision in countries with ageing populations. The ageing of nations is caused by declines in both fertility and mortality, leading to an increase in a population's median age and to a diminishing ratio of workingage people to retired people. The effect of ageing populations combined with urbanisation means that retirees have less access to traditional old-age safety nets of extended families and communities (Holzmann et al., 1999). Therefore, the role of formal retirement saving is becoming increasingly important. This poses challenges for policymakers and individuals alike. Retirees bear the responsibility for ensuring that they have accumulated adequate retirement wealth that will allow them to satisfy their consumption needs throughout their lives. In order to ensure the sustainability of pension systems, the World Bank (1994) recommended a threepillar pension system consisting of: (i) publicly managed pensions which alleviate poverty and redistribute resources among retirees (ii) privately managed, earningsrelated funded pensions which address income replacement and (iii) voluntary savings outside the formal pension system, in the forms of financial assets, insurance, housing etc. Dividing investments under a three-pillar pension system allows for risk alleviation through investments in multiple assets.

In Ireland, the Pensioner Support Ratio (the ratio of working age people to people 65 and over) is projected to decrease from 5.4 to 1 in 2010 to 2.3 to 1 in 2055 (Eurostat, 2012). Concerns over the strain on the public finances caused by future pension commitments have been reported in various Irish publications. The Department of Social and Family Affairs, 2007 report on future pension provision states that although Ireland's population will age later than most other European countries due to a relatively recent decline in fertility and net emigration before the 1990s, the country faces a challenge of growing pension costs. The European Commission has recently estimated that in Ireland, gross public pension expenditure was 7.5 per cent of GDP in 2010 and that this will rise to 11.4 per cent of GDP in 2050 or 11.7 per cent of GDP in 2060 (European Commission, 2012) 
Turning to policy in Ireland, the Pensions Board in the National Pensions Policy Initiative (1998) set a target for a supplementary pension coverage rate of 70 per cent for the workforce over the age of 30, and a target retirement income replacement rate of 50 per cent of gross pre-retirement income subject to a minimum of 34 per cent of average industrial earnings. The subsequent Green Paper on Pensions (Department of Social and Family Affairs, 2007) suggests that the targets could only be met through the introduction of mandatory supplementary pension coverage. A plan to introduce a "soft-mandatory" supplementary pension to all employees was put in place in the National Pensions Framework (Department of Social and Family Affairs, 2010). It suggests that employees would automatically be enrolled into a pension scheme unless already a member of their employer's scheme with higher contribution levels. The employee may opt out of the scheme if they wished. The introduction of this new system, however, has been postponed due to the current economic recession.

\subsection{The Irish pension system}

Traditionally, European pension systems can be divided into two main types: Bismarckian and Beveridgean, the first of which are typical of continental Europe. State welfare pensions are in general compulsory for workers, entitlements are strongly linked to contributions, and retirement income replacement rates are high. Beveridgean systems on the other hand are traditional in Anglo-Saxon countries. Membership in State welfare pensions is universal and the link between contributions and benefits is weaker, with the State providing a flat-rate payment which guarantees a minimum level of retirement income.

The Irish pension system is of the Beveridgean type and can be divided into three pillars: State welfare pensions, occupational pensions and private pensions (see Figure 1 below). The State provides flat-rate welfare pensions, the aim of which is to act as a safety net to keep retirees' incomes from falling below a certain threshold. The Irish State welfare pensions consist of contributory and noncontributory pensions. Entitlements to the first of these are built up over the career of an individual through the accumulation of Pay-Related Social Insurance (PRSI) credits. The maximum amount available in 2010 when the majority of TILDA data was collected was $€ 230.30$ per week. The second type of State welfare pension is the non-contributory pension, which is means-tested and, in 2010, was capped at $€ 219$ per week (Department of Social Protection, 2010).

Occupational and private pensions make up the remaining two pillars. They supplement State welfare pensions in facilitating workers' accumulation of assets with which they can replace labour income in retirement. Occupational pension schemes are common in public sector employment in Ireland but are also a feature of private sector employment, especially in larger firms. Public service occupational pension schemes are in place for staff in the civil service, local authorities, the Garda 
Síochána (the Irish police), the defence forces, the health and education sectors and non-commercial State bodies. Private pension schemes make up the third pillar of the Irish system. Private pension schemes are voluntary and include Retirement Annuity Contracts (RACs), which are commonly used by the self-employed, and Personal Retirement Savings Accounts (PRSAs), which were introduced in 2002.

Supplementary pension contributions are subsidised by the State by allowing contributions to be income tax deductible. Supplementary pensions can be either defined benefit (DB) or defined contribution (DC) type schemes. DB schemes are schemes where, regardless of the returns that the fund makes, the employee receives a pre-defined percentage of final pay or similar as their pension. Therefore, in DB schemes, the employer bears the risk if the fund fails to perform as well as expected. Conversely, the employee bears the fund performance risk in DC schemes. A certain amount or percentage of salary is invested into the pension fund, and an annuity is purchased at the time of retirement which then funds an income stream for the remainder of the retiree's life.

Figure 1: The Irish pension system

\begin{tabular}{|l|l|l|}
\hline \multicolumn{3}{|c|}{ Supplementary pensions } \\
\hline State welfare pensions & Occupational pensions & Private pensions \\
\hline $\begin{array}{l}\text { Contributory and } \\
\text { non-contributory }\end{array}$ & $\begin{array}{l}\text { Public and private sector } \\
\text { Contributions from }\end{array}$ & Voluntary \\
\hline Generally flat-rate & $\begin{array}{l}\text { labour income } \\
\text { PRSAs and RACs }\end{array}$ & \\
\hline
\end{tabular}

\subsection{Theory}

The benchmark economic theory for modelling pension saving is the "life cycle hypothesis" developed by Modigliani and Brumberg (1954). Under this theory, it is assumed that consumption is smoothed over an individual's lifetime to match their "permanent" income, as opposed to consumption rising or falling with income at every point over the lifecycle. When the model is applied to retirement saving a number of assumptions are typically made so that predictions regarding behaviour on the part of individuals can be made. For example, a simple model might include an assumption that individuals have perfect information about the dates of retirement and death, future incomes, prices and interest rates. Individuals are also typically assumed to be rational and, therefore, are predicted to save when their income exceeds their permanent income and dis-save when their income is low. The accumulated wealth is used to finance consumption during retirement, and wealth is exhausted at death. 
While the assumptions just listed might appear unrealistic, many of the interesting hypotheses to emerge from this line of thinking do so when the assumptions are relaxed and the implications teased out in the context of the formal model. For example, if individuals do not have perfect information on future incomes, prices and interest rates, then the nature of their decisions might change.

Another theory which is relevant for modelling pensions is the theory of compensating pay differentials. In general, this theory refers to situations in which the wage offered for a job might be higher or lower, depending on what other characteristics are present in the job. A typical example suggests that a dangerous job might offer a higher wage compared to another which is identical in all other respects. To illustrate with a pension-related example, consider an employee who is faced with two job offers where the compensation packages in present value terms are identical. However, in one job the salary might be higher and there may be no pension. In the other, the salary could be lower, but with pension entitlements building up. Depending on the individual's preferences for consumption today as opposed to tomorrow, (s)he will decide on which job offer to take. Extending this line of thinking, it has been argued that pensions act as a mechanism for employee retention, which can be in the interest of both the employee and the employer. The employee is more committed to a long career with the firm, especially in the case of a defined benefit pension scheme where pension payments are usually linked to final year or end-of-career salary. Attracting employees by means of pension entitlements as a type of wage component can lengthen tenures and, therefore, decrease training costs as well as other costs associated with high staff turnover.

Yet another view on the issue of supplementary pension coverage is provided by the theory of segmented labour markets. Under this theory, the labour market is divided into two segments, the primary and secondary segments. In the primary segment, jobs have positive characteristics such as employer-provided training, career progression and stability. Jobs in the secondary segment are characterised by lowpay and less stability. One group of employees makes it into the primary segment but the rest are excluded through institutional features such as licences and required qualifications. The relevance to pensions is that jobs in the primary segment are more likely to provide supplementary pension coverage while jobs in the secondary segment are less likely to do so.

The life cycle hypothesis and the theory of compensating pay differentials suggest that saving through pension schemes is a rational optimisation strategy on the part of the individual, and that the decision to participate in a pension plan is determined by variables that characterise the individual, such as gender, age, number of children, marital status and education level (Hughes and Nolan, 1999). However, the segmented labour market theory literature suggests that, for certain groups within the workforce, participation in a pension scheme is not determined by choice but rather by constraints experienced by certain groups of workers. Therefore, pension coverage is assumed to be determined by variables such as industry, unionisation 
and firm size (Ghilarducci, 1992). Theories of behavioural economics offer other explanations for sub-optimal saving. Some might not be contributing because they do not understand the system and judge the costs of acquiring information to be too great relative to the potential benefits of improved pension planning. Others may be unable to plan ahead due to myopia or hyperbolic discounting.

The pension economics literature predicts that individual socio-economic variables as well as labour market, job and employment variables can all help in explaining supplementary pension coverage (Barrientos, 1998b). Dummann (2008) summarises the theoretical frameworks behind the assumptions. Looking at the characteristics of the individual that may affect the probability of pension coverage, education level is expected to be significant because the well-educated are likely to be more informed about pension saving options. Other socio-economic variables which may affect pension saving include age, marital status and the number of children. Another factor that may affect pension coverage is the size of the employer. As economies of scale also apply to pension provision, larger firms have lower costs of providing pension benefits per employee.

\subsection{Existing research}

Previous studies on the determinants of pension coverage and pension scheme participation include papers by Holzmann et al. (1999), Barrientos (1998a, 1998b), Levine et al (1999), Dummann (2008) and an Irish study by Hughes and Nolan (1999). Holzmann et al. (1999) use data from Chile and Argentina to estimate probit models to assess the determinants of the probability of individuals contributing to a pension scheme using individual, household and locational characteristics. They find that individuals with low incomes, low education levels and those who are self-employed are less likely to contribute to pension plans. Barrientos (1998a) analyses gender differences in pension coverage in Chile by using a similar regression approach to that used by Holzmann et al. (1999), and finds that age, employment history, firm size, occupational indicators, income levels and location are all significant in determining the probability of an individual participating in a pension plan. Barrientos (1998b) uses the 1993-1994 Family Resources Survey to study which groups in Britain are less likely to be covered by supplementary pensions. He finds that the group without a pension is more likely to consist of women, the low-skilled, individuals with low education and part-time workers. Levine et al. (1999) have investigated how work history characteristics affect income differentials beween men and women. They find that a longer work history and higher prime-age earnings increase retirement income levels, whereas working in female-intensive occupations has the opposite effect.

Studies of the Irish pension system have previously suffered from the unavailability of appropriate data. This paper adds to the existing literature by utilising the TILDA 
data, described in the subsequent section. The multi-disciplinary dimensions of TILDA allow for the inclusion of control variables that are absent in much of the existing analyses. In the Irish pensions literature, existing work has focused mainly on the financial situation of the elderly population as a whole, and the analysis has been descriptive for the most part. The studies report figures on poverty rates, deprivation rates and the relative importance of various income sources (Layte et al., 1999; Central Statistics Office, 2011; Baroni and O'Donoghue, 2009). In these studies, the inadequacy of retirement saving has been reported especially in the cases of women and those with part-time or non-continuous work histories.

Hughes and Nolan (1999) carried out an analysis of pension entitlement in Ireland using data from the Living in Ireland Survey of 1994. According to their findings, certain groups of workers in Ireland have life-long consequences of their type of occupation - in terms of not acquiring a supplementary pension while working and not having the time or the resources to make alternative arrangements. These workers depend solely on the State for their retirement incomes. 


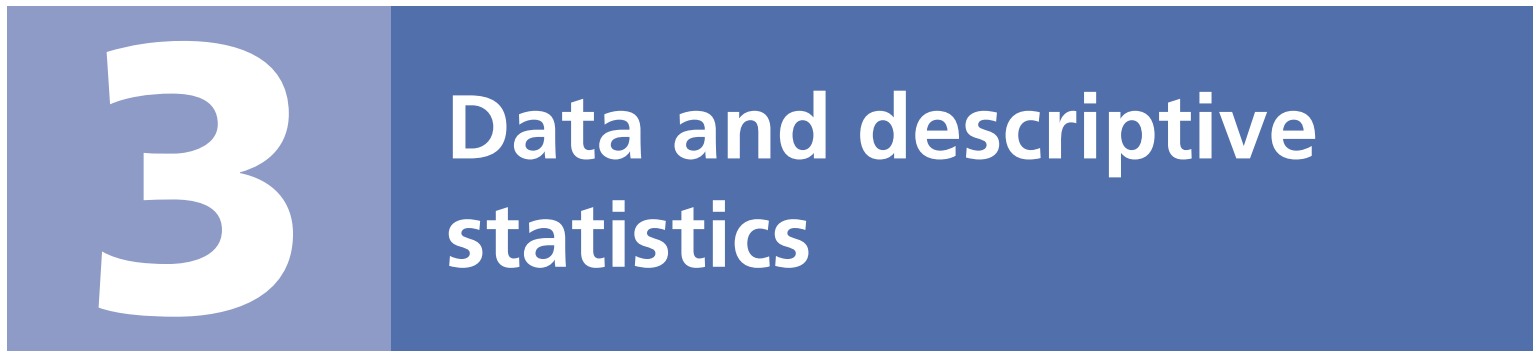

\subsection{Data}

This paper uses recent data from the Irish Longitudinal Study on Ageing (TILDA), a nationally representative sample of the older Irish population. TILDA contains information on 8,504 individuals who were aged 50 or older at the time of data collection, which took place between 2009 and 2011. The sample used in this analysis is restricted to individuals who state that they are fully retired, and who have a relatively substantial working history (more than 10 years for women, more than 15 years for men). The income components included in the retirement income calculations are (contributory and non-contributory) social welfare pensions, occupational pensions, private pensions and other non-pension social welfare payments. The focus is on these income sources because they can be seen as replacing pre-retirement income from labour and are accumulated through the formal pension system (in the case of State welfare pensions and occupational and private pensions) or provided by the State to assist low-income retirees. The analysis is carried out at the individual rather than the household level because the focus of the paper is on the way in which the Irish pension system provides retirement income for individuals with different socio-economic backgrounds and labour market participation histories. The sample used in this analysis is made up of 1,781 individuals who meet our restricting criteria and who provide information about their current incomes and the other necessary variables.

\subsection{Descriptive statistics}

Before describing the breakdown of retirees' incomes, we should point out that our sample is heavily skewed towards men. Almost two-thirds (63.4 per cent) of the individuals in the sample used in this analysis are male, compared to just over a third who are female. This arises because of the higher labour market participation rates among (especially older) men in Ireland.

In Table 1, we provide two perspectives on the incomes of retirees. In the first panel for men and women (labelled ' $a$ '), we show the percentages that receive the various forms of retirement income - the two types of State welfare pensions, occupational pensions, private pensions and other social welfare payments. In the second pane (labelled ' $b$ '), we show the average weekly amounts. The last column in the table refers to the full sample but we also show how the pattern varies across income 
Table 1: Pension income sources

\begin{tabular}{|c|c|c|c|c|c|}
\hline Men & $\begin{array}{c}\text { 1st } \\
\text { income } \\
\text { quartile }\end{array}$ & $\begin{array}{l}\text { 2nd } \\
\text { income } \\
\text { quartile }\end{array}$ & $\begin{array}{c}\text { 3rd } \\
\text { income } \\
\text { quartile }\end{array}$ & $\begin{array}{l}\text { 4th } \\
\text { income } \\
\text { quartile }\end{array}$ & Total \\
\hline \multicolumn{6}{|l|}{ a) Percentage of individuals receive } \\
\hline Contributory State welfare pension & 59.6 & 80.6 & 79.3 & 72.0 & 70.7 \\
\hline Non-contributory State welfare pension & 27.9 & 15.9 & 6.5 & 3.7 & 15.6 \\
\hline Occupational pension & 6.0 & 35.8 & 74.1 & 96.1 & 46.1 \\
\hline Private pension & 2.8 & 3.8 & 9.0 & 7.3 & 5.4 \\
\hline Social welfare & 10.5 & 10.2 & 11.3 & 7.4 & 10.1 \\
\hline \multicolumn{6}{|c|}{ b) Mean individual income, EURO per week } \\
\hline Contributory State welfare pension & $\begin{array}{c}122.9 \\
(107.5)\end{array}$ & $\begin{array}{l}185.0 \\
(95.1)\end{array}$ & $\begin{array}{c}201.0 \\
(120.9)\end{array}$ & $\begin{array}{c}176.4 \\
(139.4)\end{array}$ & $\begin{array}{r}164.0 \\
(120.5)\end{array}$ \\
\hline Non-contributory State welfare pension & $\begin{array}{c}53.7 \\
(90.9)\end{array}$ & $\begin{array}{c}36.7 \\
(85.2)\end{array}$ & $\begin{array}{c}15.1 \\
(62.6)\end{array}$ & $\begin{array}{c}9.2 \\
(47.2)\end{array}$ & $\begin{array}{c}32.2 \\
(78.4)\end{array}$ \\
\hline Occupational pension & $\begin{array}{c}5.5 \\
(28.1)\end{array}$ & $\begin{array}{c}20.5 \\
(50.1)\end{array}$ & $\begin{array}{c}143.8 \\
(144.7)\end{array}$ & $\begin{array}{c}691.7 \\
(504.9)\end{array}$ & $\begin{array}{c}177.7 \\
(351.0)\end{array}$ \\
\hline Private pension & $\begin{array}{c}2.2 \\
(16.2)\end{array}$ & $\begin{array}{c}0.9 \\
(4.8)\end{array}$ & $\begin{array}{c}13.1 \\
(51.4)\end{array}$ & $\begin{array}{c}54.7 \\
(277.1)\end{array}$ & $\begin{array}{r}15.0 \\
(127.1)\end{array}$ \\
\hline Social welfare & $\begin{array}{c}6.0 \\
(30.2)\end{array}$ & $\begin{array}{r}4.1 \\
(20.5)\end{array}$ & $\begin{array}{c}10.0 \\
(41.5)\end{array}$ & $\begin{array}{c}6.0 \\
(30.4)\end{array}$ & $\begin{array}{r}6.7 \\
(32.3)\end{array}$ \\
\hline
\end{tabular}

\begin{tabular}{|c|c|c|c|c|c|}
\hline Women & $\begin{array}{c}\text { 1st } \\
\text { income } \\
\text { quartile }\end{array}$ & $\begin{array}{l}\text { 2nd } \\
\text { income } \\
\text { quartile }\end{array}$ & $\begin{array}{c}\text { 3rd } \\
\text { income } \\
\text { quartile }\end{array}$ & $\begin{array}{c}\text { 4th } \\
\text { income } \\
\text { quartile }\end{array}$ & Total \\
\hline \multicolumn{6}{|l|}{ a) Percentage of individuals receive } \\
\hline Contributory State welfare pension & 16.3 & 75.6 & 73.8 & 60.7 & 56.4 \\
\hline Non-contributory State welfare pension & 20.9 & 22.9 & 16.3 & 5.5 & 17.6 \\
\hline Occupational pension & 24.7 & 3.0 & 33.9 & 91.4 & 32.6 \\
\hline Private pension & 1.5 & 0.8 & 9.1 & 4.8 & 3.6 \\
\hline Social welfare & 24.3 & 2.8 & 18.4 & 13.6 & 14.2 \\
\hline \multicolumn{6}{|c|}{ b) Mean individual income, EURO per week } \\
\hline Contributory State welfare pension & $\begin{array}{c}23.1 \\
(54.2)\end{array}$ & $\begin{array}{l}169.1 \\
(97.6)\end{array}$ & $\begin{array}{c}171.7 \\
(105.4)\end{array}$ & $\begin{array}{c}132.1 \\
(121.1)\end{array}$ & $\begin{array}{c}123.2 \\
(133.8)\end{array}$ \\
\hline Non-contributory State welfare pension & $\begin{array}{c}31.2 \\
(65.1)\end{array}$ & $\begin{array}{c}48.7 \\
(90.8)\end{array}$ & $\begin{array}{c}38.1 \\
(87.8)\end{array}$ & $\begin{array}{r}9.5 \\
(42.7)\end{array}$ & $\begin{array}{r}34.1 \\
(77.4)\end{array}$ \\
\hline Occupational pension & $\begin{array}{c}18.9 \\
(43.1)\end{array}$ & $\begin{array}{c}2.0 \\
(17.5)\end{array}$ & $\begin{array}{c}32.8 \\
(69.4)\end{array}$ & $\begin{array}{c}377.6 \\
(258.3)\end{array}$ & $\begin{array}{r}84.7 \\
(185.5)\end{array}$ \\
\hline Private pension & $\begin{array}{c}0.7 \\
(7.0)\end{array}$ & $\begin{array}{c}0.0 \\
(0.1)\end{array}$ & $\begin{array}{c}2.8 \\
(11.5)\end{array}$ & $\begin{array}{c}4.8 \\
(27.0)\end{array}$ & $\begin{array}{r}1.8 \\
(13.6)\end{array}$ \\
\hline Social welfare & $\begin{array}{c}15.6 \\
(40.0)\end{array}$ & $\begin{array}{c}4.1 \\
(28.3)\end{array}$ & $\begin{array}{c}12.3 \\
(40.8)\end{array}$ & $\begin{array}{c}13.7 \\
(54.0)\end{array}$ & $\begin{array}{r}10.9 \\
(40.4)\end{array}$ \\
\hline
\end{tabular}

Note: Parts (a) show the percentages of the men and women who receive income from the listed sources by total income quartile, and for the total sample. Parts (b) show the means and the standard deviations (in parentheses) of the weekly EURO amounts received, unconditional on receiving income from that source. 
deciles. The mean weekly pension income of men in the sample is $€ 397$ - this is the sum of the five amounts in the last column. This is 58 per cent higher than the average pension income of women - $€ 252$. For men, the largest share ( $€ 177$ of the 397 or 45 per cent) of total income on average comes from occupational pensions, while for women the largest share comes from contributory State welfare pensions (49 per cent of total income on average). 86 per cent of the men in our sample and 74 per cent of women receive a State welfare pension, with men having a higher coverage rate for the contributory State welfare pension, whereas a higher percentage of women receive the means-tested non-contributory State welfare pension. Overall, 45 per cent of all individuals receive income from supplementary pensions (occupational or private pensions). 46 per cent of men and 33 per cent of women have occupational pensions, whereas the coverage rate for private pensions is much lower for both men and women at 5 per cent and 4 per cent respectively. As PRSAs were not introduced until 2002, the analysis of current retirees is likely to underestimate the coverage of PRSA accounts of future retirees. One out of ten men and one out of seven women report receiving income from social welfare payments, other than pensions.

In Figure 2 we present a graphical representation of the incomes of the retirees. The distribution of income is shown to be highly skewed, with the most notable peaks in the distribution in the categories of 201-250 and $€$ 0-50 per week. The peak of the distribution between 200 and 250 EUR per week reflects the fact that the 2010 flatrate State welfare pensions (contributory and non-contributory) were both within this bracket, at $€ 230$ and $€ 219$ per week, respectively, when the majority of the TILDA data were collected. The group of individuals whose income is less than $€ 50$ per week are mainly women (76 per cent). Conversely, 95 per cent of the individuals with incomes in excess of $€ 1,000$ per week are men. There is a notable share of individuals who report their income levels to be zero. Even though these individuals report not having any income from the sources included in this analysis, they are likely to be members of households whose total income is non-zero. 
Figure 2: Distribution of pension income (EURO per week) by gender



Figures 3-6 depict income levels and compositions between retiree sub-groups. Figure 3 shows the structure of retirement income across income levels and so is similar in content to Table 1 above. It is clear that for those with lower incomes, State welfare pensions play an important role. On average, State welfare pensions constitute more than 90 per cent of total income for those whose income is less than $€ 250$ per week. For those with higher incomes, supplementary (mainly occupational) pensions are more important. For individuals in a high income category of over $€ 750$ per week, supplementary pensions make up over 80 per cent of total income.

The significance of the length of working history is depicted in Figure 4. In this case, we show men and women separately because of their very different patterns of work history. The generally higher incomes of men are apparent but the patterns across the different work histories are similar. On average, individuals of both genders with long working careers - between 35 and 45 years - have higher retirement income levels than those who have either worked for less than $\mathbf{4 0}$ or for more than 50 years. It seems that individuals with long working histories have been able to accumulate more substantial retirement wealth by contributing into supplementary pension funds. However, individuals with working histories of 50 years or longer have lower average retirement income levels, which may be explained by the lower education levels within this group compared to those who have shorter work histories. 
7 per cent of the individuals who have worked for 50 years or more have third level education, compared to 16 per cent of those who have worked for less than 50 years.

Figure 5 shows the importance of education in determining retirement income levels later in life. Those with primary level education (or less) have retirement incomes of $€ 277$ per week on average, while those with third level degrees or higher have weekly incomes of $€ 589$ on average. The sizeable difference in income levels and compositions between those previously employed in the private sector and in the public sector is depicted in Figure 6. The income of individuals whose last employment before retirement was in the public sector is on average 54 per cent higher than the income of those who worked in the private sector. Occupational pensions make up more than half of total income of public sector retirees whereas former private sector retirees receive less than a quarter of their total retirement income from occupational pensions.

Figure 3: Share of mean total income from different sources, by total income level (EURO/week)

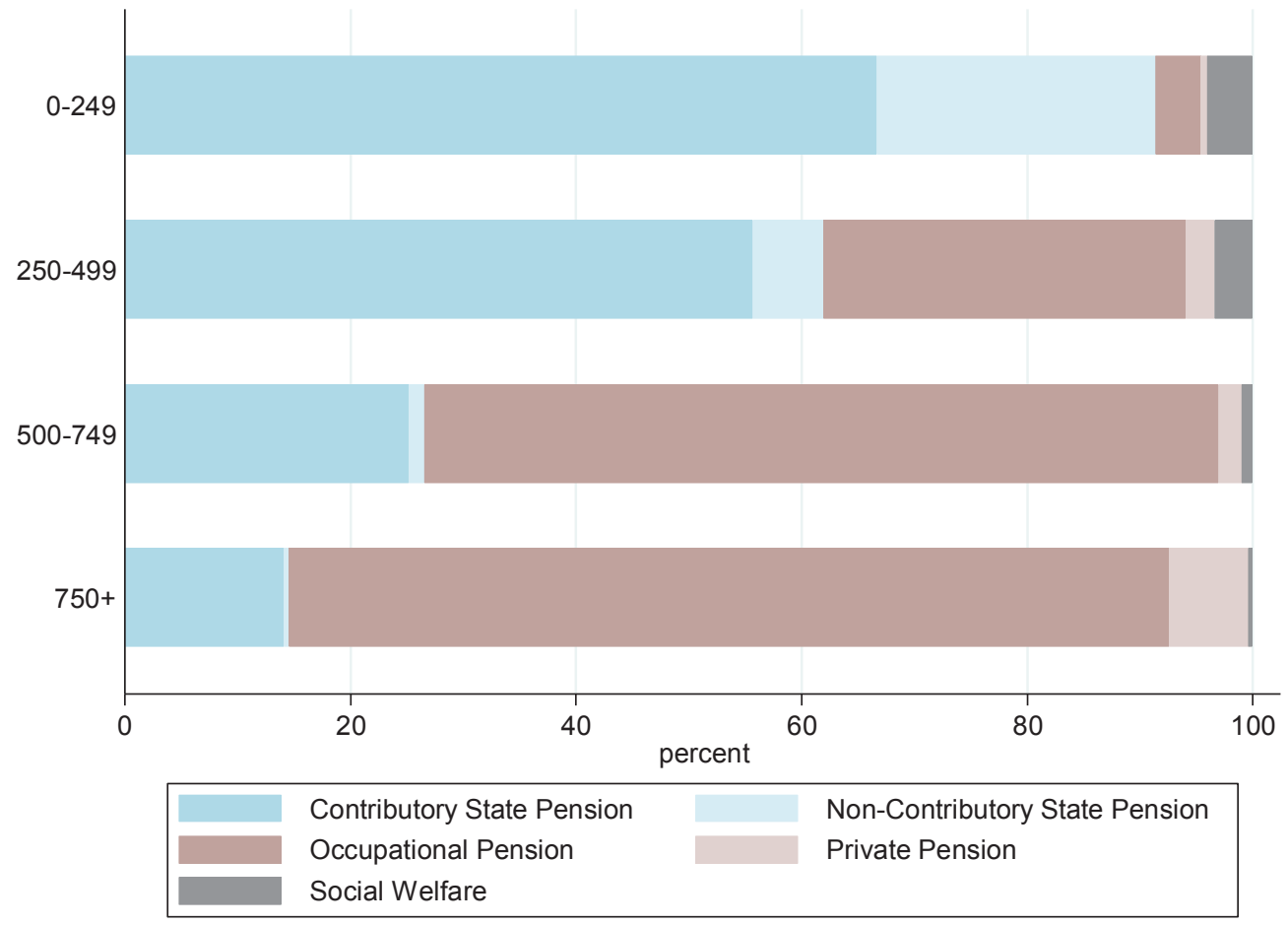


Figure 4: Mean income (EURO/week) and income components, by length of work history (years)

\section{Men}

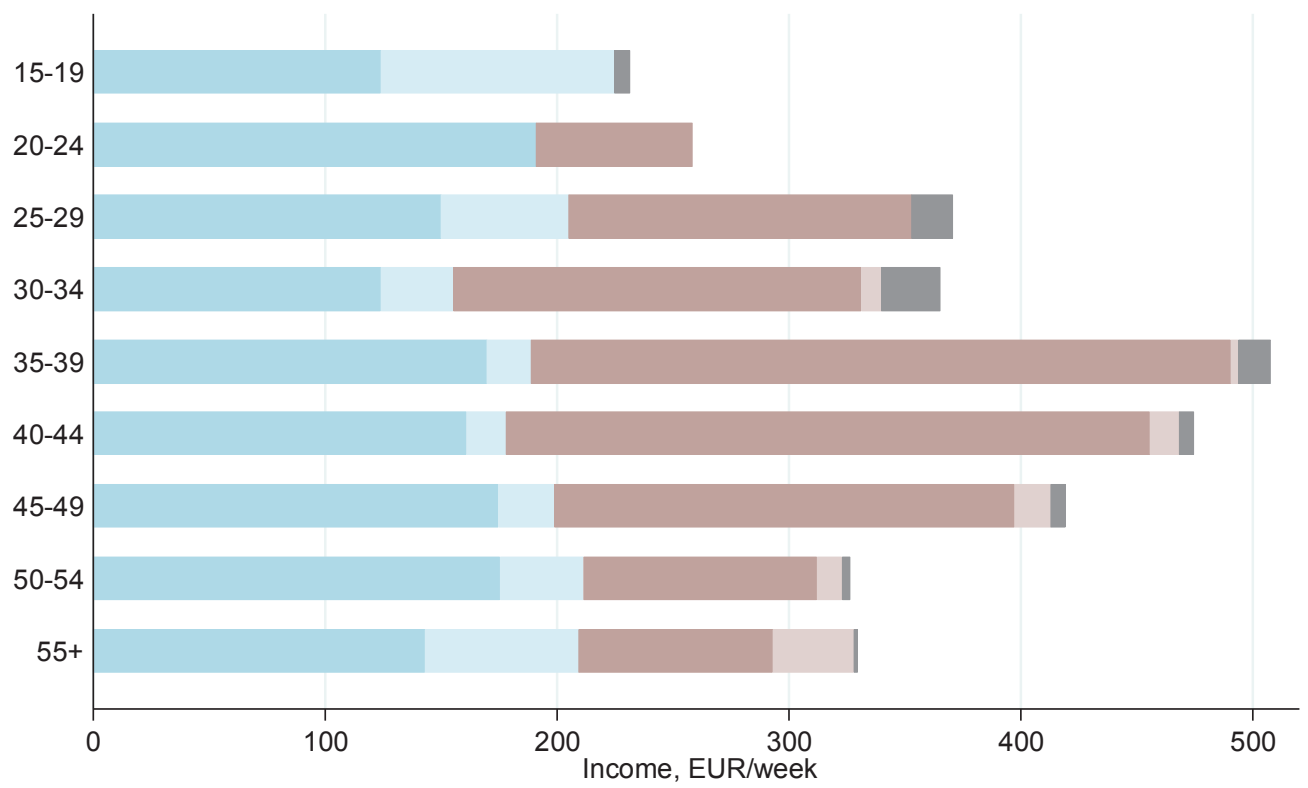

\section{Women}



${ }^{*}$ EUR $=$ EURO 
Figure 5: Mean income (EURO/week) and income components, by education level

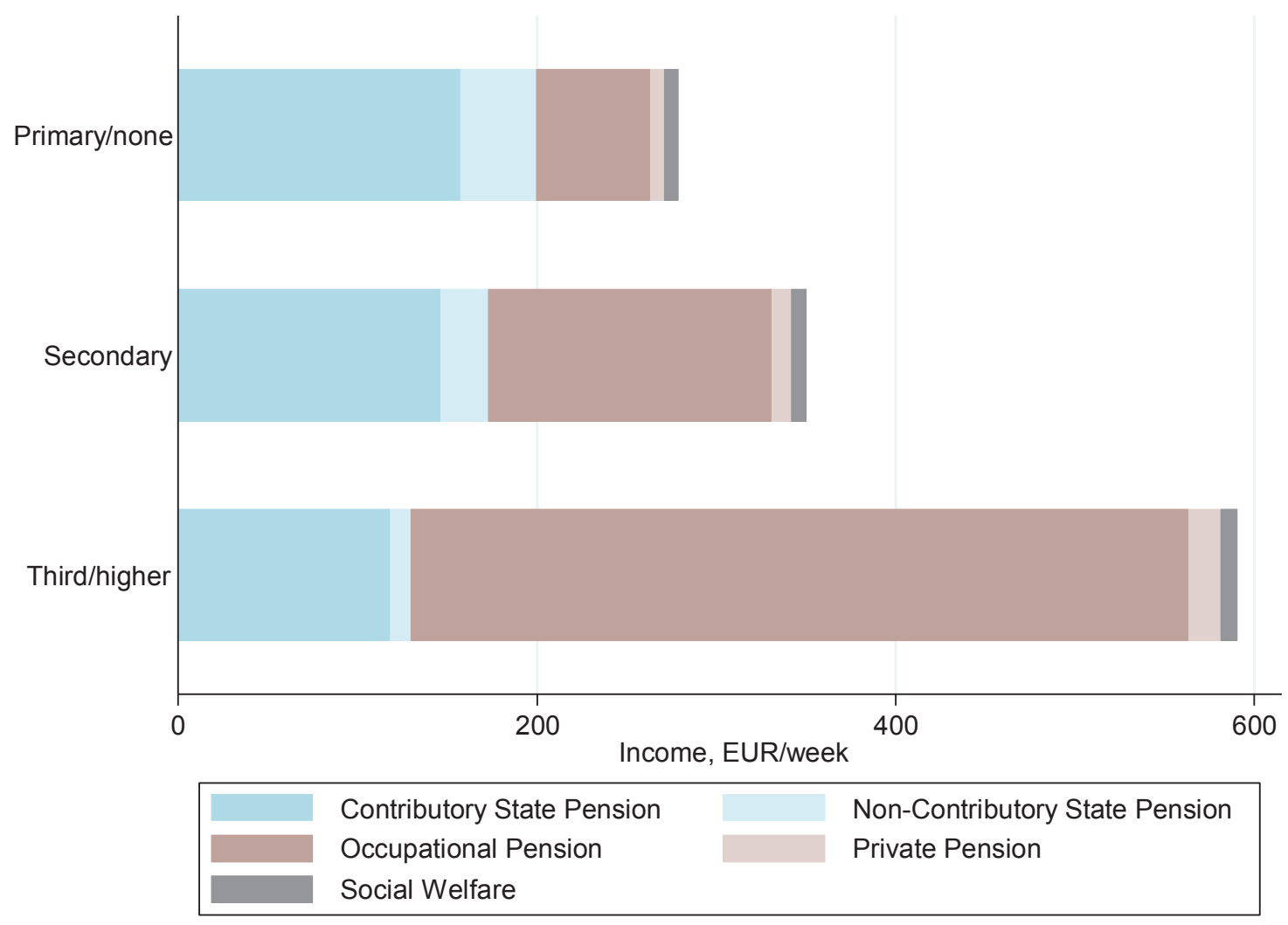

${ }^{*} E U R=E U R O$ 
Figure 6: Mean income (EURO/week) and income components, by sector of employment

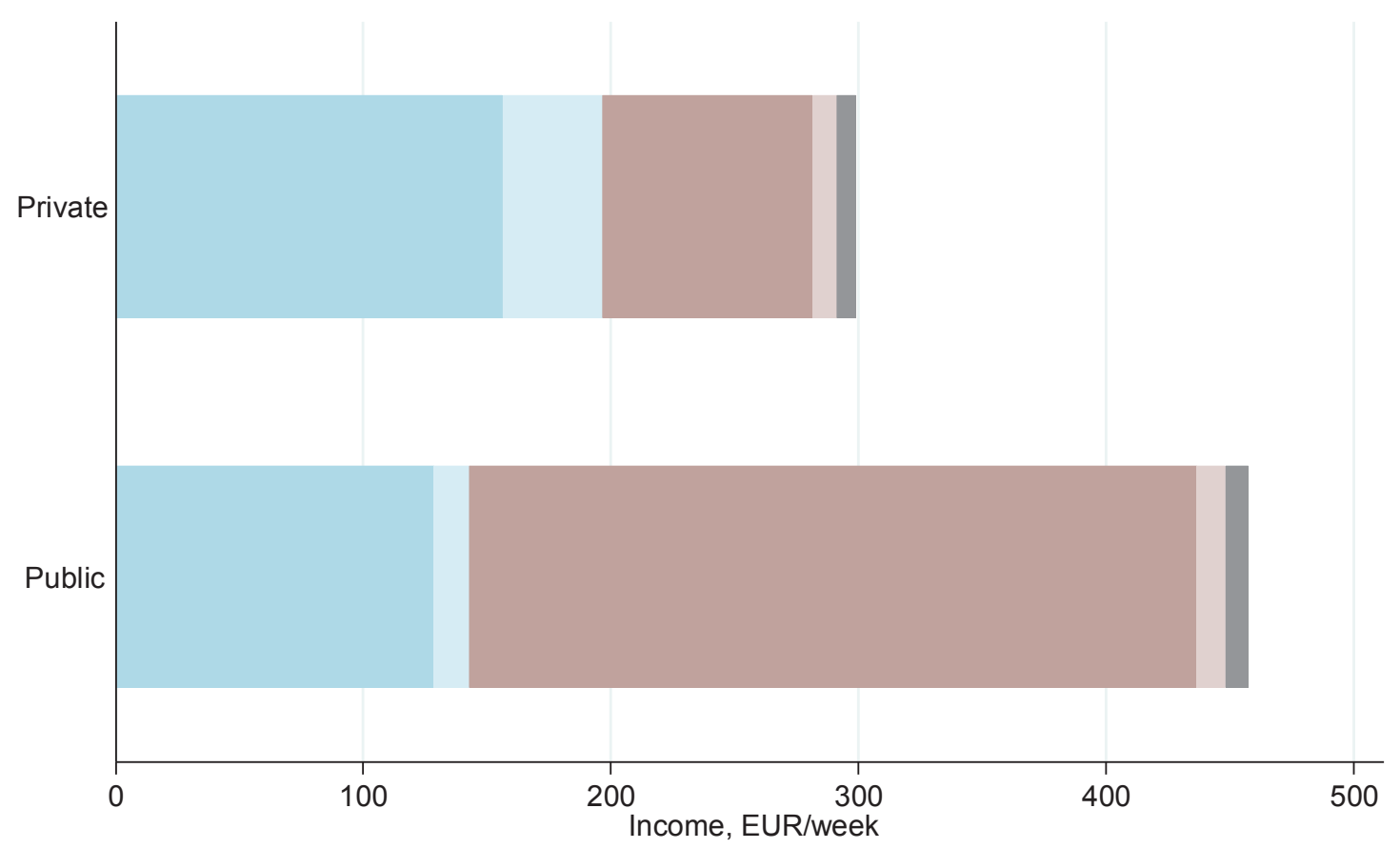

Contributory State Pension

Non-Contributory State Pension Occupational Pension

Private Pension

Social Welfare 


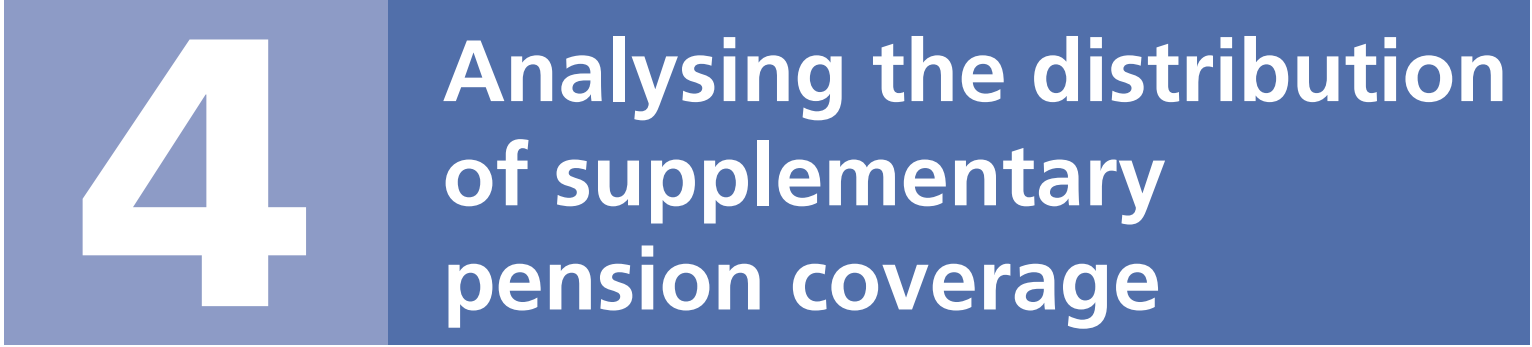

\subsection{The modelling technique and the variables}

Having established in the first part of the analysis that supplementary pensions explain most of the variance in retiree pension income levels, this section of the paper examines the determinants of supplementary pension coverage. The analysis is carried out using a probit estimation technique. As the dependent variable in the analysis is a binary variable (individuals either have a supplementary pension or they do not), the more standard ordinary least square regression would not be approporiate. Using the probit estimation technique, the probability of an individual receiving income from a supplementary pension coverage is modelled as a function of individual socio-economic and job history characteristics. As the coefficients of a probit model cannot be interpreted directly, the marginal effects must be calculated and these marginal effects are reported in the tables below.

The first part of Table 2 presents the individual socio-economic variables used in the analysis and their expected coefficient signs. Within the sample used in this analysis, age is expected to be negatively correlated with supplementary pension coverage because pension coverage has in general been increasing in Ireland in the past. Education, childhood poverty and home ownership are all predictors of income, and are therefore expected to affect pension coverage. The total number of years worked and years worked in the last employment before retirement are likely to enter with a positive coefficient because working history and job tenure both decrease the risk of adverse shocks to earnings and, therefore, increase the likelihood of participating in a saving scheme. However, the magnitude of the effect is expected to decrease with years worked, and therefore, the squared terms are expected to be negatively associated with the dependent variable. The models also control for self-reported health status and geographical location dummies. The second part of Table 2 presents the job characteristic variables and their expected coefficient signs. The indicators for firm size are expected to be significant in determining pension coverage because of economies of scale in pension provision experienced by larger firms.

Table 3 presents the percentages of individuals belonging to different individual socio-economic and work history indicator groups, and the supplementary pension coverage rates observed in these groups. Table 4 presents the same statistics for job type characteristics. The coverage rates for supplementary pension plans are highly differentiated depending on individual characteristics. On average, the women in the sample are more educated, have shorter job tenures, less likely to live in rural areas, more likely to have worked part-time, less likely to have professional or managerial jobs and are less likely to have supplementary pensions (35.3 versus 50.9 per cent). 
Table 2: Descriptions and expected signs of the variables. Dependent variable (SUPP_i) and vector of explanatory variables of individual $i$

\begin{tabular}{|c|c|c|}
\hline Variable & Description & Expected sign \\
\hline SUPP $_{i}$ & $\begin{array}{l}\text { Dummy variable equal to } 1 \text { if individual i receives } \\
\text { income from a supplementary pension, } 0 \text { otherwise }\end{array}$ & \\
\hline \multicolumn{3}{|c|}{ Individual characteristics } \\
\hline $\mathrm{AGE}_{\mathrm{i}}$ & Age (years) of individual i & - \\
\hline $\mathrm{KIDS}_{\mathrm{i}}$ & Number of living children of individual i & - \\
\hline MARRIED $_{i}$ & $\begin{array}{l}\text { Dummy variable equal to } 1 \text { if individual } i \text { is } \\
\text { married or cohabiting in a married-like relationship, } \\
0 \text { otherwise }\end{array}$ & men + , women - \\
\hline SECONDARY $_{i}$ & $\begin{array}{l}\text { Dummy variable equal to } 1 \text { if individual i's highest } \\
\text { education level is at secondary level, } 0 \text { otherwise }{ }^{1}\end{array}$ & + \\
\hline THIRD $_{i}$ & $\begin{array}{l}\text { Dummy variable equal to } 1 \text { if individual i's highest } \\
\text { education level is at third level, } 0 \text { otherwise }{ }^{1}\end{array}$ & + \\
\hline POOR $_{\mathrm{i}}$ & $\begin{array}{l}\text { Dummy variable equal to } 1 \text { if individual i's family } \\
\text { financial situation was poor from birth to age } 14, \\
0 \text { otherwise }\end{array}$ & - \\
\hline HOME $_{i}$ & $\begin{array}{l}\text { Dummy variable equal to } 1 \text { if individual i or their } \\
\text { spouse owns their primary residence, } 0 \text { otherwise }\end{array}$ & + \\
\hline YRSWORKED $_{i}$ & $\begin{array}{l}\text { Number of years individual i has worked since } \\
\text { leaving education }\end{array}$ & + \\
\hline SQYRSWORKED $_{\mathrm{i}}$ & $\begin{array}{l}\text { Squared number of years individual i has worked } \\
\text { since leaving education }\end{array}$ & - \\
\hline TENURE $_{i}$ & $\begin{array}{l}\text { Number of years individual i worked in last job } \\
\text { before retirement }\end{array}$ & + \\
\hline SQTENURE $_{\mathrm{i}}$ & $\begin{array}{l}\text { Squared number of years individual i worked in last } \\
\text { job before retirement }\end{array}$ & - \\
\hline HEALTH $_{i}$ & $\begin{array}{l}\text { Self-reported health level of individual i, ranging } \\
\text { from } 1=\text { poor to } 5=\text { excellent }\end{array}$ & + \\
\hline LOCATION $_{\mathrm{i}}$ & $\begin{array}{l}\text { Vector of dummy variables for location of individual } \\
\text { i, for Dublin, other towns, and rural }{ }^{2}\end{array}$ & - \\
\hline \multicolumn{3}{|l|}{ Job characteristics } \\
\hline PARTTIME $_{i}$ & $\begin{array}{l}\text { Dummy variable equal to } 1 \text { if individual i worked } \\
\text { part-time (less than } 30 \text { hours per week) in their last } \\
\text { employment, } 0 \text { otherwise }\end{array}$ & - \\
\hline FIRMSIZE $_{i}$ & $\begin{array}{l}\text { Vector of dummy variables for the number of } \\
\text { employees of individual i's last employment before } \\
\text { retirement }{ }^{3}\end{array}$ & large + \\
\hline OCCUPATION $_{\mathrm{i}}$ & $\begin{array}{l}\text { Vector of dummy variables for the occupation of } \\
\text { individual i's last employment before retirement }\end{array}$ & $\begin{array}{c}\text { professional, managerial, } \\
\text { non-manual + }\end{array}$ \\
\hline PUBLIC $_{\mathrm{i}}$ & $\begin{array}{l}\text { Dummy variable equal to } 1 \text { if individual i worked } \\
\text { in the public sector in their last employment before } \\
\text { retirement, } 0 \text { otherwise }\end{array}$ & + \\
\hline
\end{tabular}

${ }^{1}$ reference category: no formal education/primary level

${ }^{2}$ reference category: Dublin

${ }^{3}$ reference category: unskilled/unknown 
Table 3: Summary statistics of individual socio-economic and work history variables by gender

\begin{tabular}{|c|c|c|c|c|c|}
\hline & & \multicolumn{2}{|c|}{ Percentage in category } & \multicolumn{2}{|c|}{$\begin{array}{l}\text { Percentage with } \\
\text { supplementary pension }\end{array}$} \\
\hline & & Male (\%) & Female (\%) & Male (\%) & Female (\%) \\
\hline \multirow{2}{*}{$\begin{array}{l}\text { Has supplementary } \\
\text { pension }\end{array}$} & Yes & 50.88 & 35.25 & & \\
\hline & No & 49.12 & 64.75 & & \\
\hline \multirow[t]{5}{*}{ Age } & $65-69$ & 31.16 & 31.37 & 56.43 & 38.18 \\
\hline & 70-74 & 28.76 & 24.88 & 49.85 & 34.99 \\
\hline & $75-79$ & 20.72 & 24.50 & 51.18 & 28.25 \\
\hline & $80-84$ & 12.20 & 12.02 & 42.26 & 35.10 \\
\hline & $85+$ & 7.16 & 7.22 & 44.75 & 47.35 \\
\hline \multirow[t]{4}{*}{ Number of children } & 0 & 19.08 & 20.41 & 35.21 & 42.09 \\
\hline & $1-2$ & 22.36 & 24.35 & 52.70 & 31.91 \\
\hline & 3-4 & 36.39 & 35.80 & 58.57 & 33.10 \\
\hline & $5+$ & 22.17 & 19.43 & 50.87 & 36.18 \\
\hline \multirow[t]{2}{*}{ Married } & Yes & 66.47 & 44.19 & 55.61 & 31.74 \\
\hline & No & 33.53 & 55.81 & 41.52 & 38.02 \\
\hline \multirow[t]{3}{*}{ Education } & None/primary & 58.94 & 48.08 & 25.27 & 25.27 \\
\hline & Secondary & 29.45 & 35.76 & 34.03 & 34.03 \\
\hline & Third level & 11.62 & 16.16 & 67.34 & 67.34 \\
\hline \multirow[t]{2}{*}{ Poor as child } & Yes & 30.15 & 22.70 & 49.22 & 28.66 \\
\hline & No & 69.85 & 77.30 & 51.45 & 37.18 \\
\hline \multirow[t]{2}{*}{ Owns home } & Yes & 68.95 & 67.08 & 56.13 & 37.45 \\
\hline & No & 31.05 & 32.92 & 39.24 & 30.74 \\
\hline \multirow[t]{5}{*}{ Years worked } & $0-9$ & * & * & * & * \\
\hline & $10-19$ & 0.20 & 19.49 & * & 24.71 \\
\hline & $20-29$ & 1.97 & 17.04 & 37.09 & 32.05 \\
\hline & $30-39$ & 11.57 & 23.15 & 54.28 & 46.32 \\
\hline & $40+$ & 86.27 & 40.32 & 51.40 & 37.04 \\
\hline \multirow[t]{5}{*}{ Tenure (years) } & $0-9$ & 16.87 & 28.64 & 37.26 & 25.26 \\
\hline & $10-19$ & 18.65 & 33.14 & 44.85 & 32.75 \\
\hline & $20-29$ & 15.30 & 17.97 & 59.90 & 46.33 \\
\hline & 30-39 & 20.66 & 11.91 & 74.72 & 44.73 \\
\hline & $40+$ & 28.52 & 8.34 & 44.10 & 51.37 \\
\hline \multirow[t]{5}{*}{ Health } & Poor & 6.76 & 6.42 & 41.36 & 31.34 \\
\hline & Fair & 22.26 & 24.56 & 44.16 & 24.26 \\
\hline & Good & 36.62 & 35.81 & 50.27 & 38.29 \\
\hline & Very good & 24.42 & 22.52 & 54.73 & 41.11 \\
\hline & Excellent & 9.94 & 10.70 & 65.22 & 40.26 \\
\hline \multirow[t]{3}{*}{ Location } & Dublin & 23.39 & 30.29 & 72.52 & 43.69 \\
\hline & Town & 29.32 & 32.18 & 54.04 & 27.87 \\
\hline & Rural & 47.29 & 37.53 & 38.57 & 34.75 \\
\hline
\end{tabular}


Table 4: Summary statistics of job type variables by gender

\begin{tabular}{|c|c|c|c|c|c|}
\hline & & \multicolumn{2}{|c|}{ Percentage in category } & \multicolumn{2}{|c|}{$\begin{array}{c}\text { Percentage with } \\
\text { supplementary pension }\end{array}$} \\
\hline & & $\begin{array}{l}\text { Male } \\
(\%)\end{array}$ & $\begin{array}{l}\text { Female } \\
\qquad(\%)\end{array}$ & $\begin{array}{l}\text { Male } \\
(\%)\end{array}$ & $\begin{array}{c}\text { Female } \\
(\%)\end{array}$ \\
\hline \multirow[t]{2}{*}{ Part-time } & Yes & 6.08 & 36.49 & 45.07 & 29.30 \\
\hline & No & 93.92 & 63.51 & 51.71 & 38.93 \\
\hline \multirow[t]{6}{*}{ Firm size (employees) } & $1-5$ & 32.81 & 30.42 & 24.40 & 16.45 \\
\hline & $6-15$ & 13.41 & 17.12 & 45.80 & 30.71 \\
\hline & $16-24$ & 7.73 & 9.35 & 56.68 & 35.09 \\
\hline & 25-199 & 23.21 & 22.68 & 66.73 & 41.24 \\
\hline & $200-499$ & 9.36 & 8.71 & 70.41 & 58.87 \\
\hline & $500+$ & 12.12 & 9.73 & 83.42 & 70.85 \\
\hline \multirow[t]{7}{*}{ Occupation } & Unskilled/unknown & 13.32 & 16.18 & 77.60 & 51.43 \\
\hline & Professional & 4.37 & 1.24 & 81.24 & 52.99 \\
\hline & Managerial & 18.73 & 26.17 & 61.51 & 37.48 \\
\hline & Non-manual & 9.95 & 23.56 & 39.66 & 17.83 \\
\hline & Skilled manual & 22.88 & 12.36 & 57.90 & 25.49 \\
\hline & Semi-skilled & 18.10 & 17.13 & 13.10 & 20.21 \\
\hline & Farmer & 12.67 & 3.35 & 37.18 & 28.78 \\
\hline \multirow[t]{2}{*}{ Sector of employment } & Public & 24.73 & 32.90 & 83.14 & 60.65 \\
\hline & Private & 75.27 & 67.10 & 40.15 & 22.77 \\
\hline
\end{tabular}


This section of the paper presents the results of the probit model analysis. The models are estimated separately for men and women as the regressors may have effects which are different in magnitude and direction depending on gender.

The results from the probit model analyses are presented in Table 5 for men and Table 6 for women. The findings are largely as expected. The models in columns 1 of both tables only incorporate individual socio-economic characteristics: age, number of living children, a dummy for marital status, educational dummies, a dummy for poor financial situation in childhood, home ownership, years worked, health status and location dummies. For men, being married has a positive significant effect on the probability of having a supplementary pension whereas the effect is negative although not statistically significant for women. Higher education levels have a positive effect for both genders, as expected. Owning the residential home has a positive coefficient which is highly significant for men. Interestingly, the coefficients on years worked and squared years worked are not statistically significant for men even though the signs are as predicted. However, in column 1 of Table 6, we see that years worked is statistically significant for women.

The models in columns 2 include job tenure and tenure squared, which are significant in explaining supplementary pension coverage for both men and for women. The mechanism behind this finding may be that the length of time with the same employer is a key determinant of pension coverage rather than the total number of years spent in work, because the latter can be non-continuous. Also, length of job tenure in the last employment before retirement is likely to have a significant impact on pension saving behaviour as individuals are likely to prepare for their retirement the further they are in their working careers. There is an issue of possible reverse causality explaining the significance of job tenure. Perhaps individuals do not acquire a pension because of a long-term employment contract but rather they remain in the same job due to generous pension entitlements, especially in the later stages of their career. Better overall health levels and living in Dublin versus other towns or rural areas also have statistically significant positive effects on the dependent variable.

The model in column 3 investigates the effects of job characteristics on the probability of an individual receiving income from a supplementary pension. As expected, the coefficients are positive and significant for larger firm size (firm size of 1-5 employees being the reference category). The coefficient also grows in magnitude with firm size. Confirming prior expectations, the coefficients for managerial, professional and non-manual occupations have significant positive coefficients, compared with the reference category of unskilled or unknown occupations. The coefficient for the public sector employment indicator dummy shows that employment sector plays an important role in supplementary pension coverage determination in Ireland. 
The models in columns 4 combine the individual and job type characteristics, and most of the results remain broadly the same, with third level education, home-ownership, geographical location, firm size, the public sector dummy and occupational dummies remaining significant. However, the impact of tenure and experience across men and women is complicated. For women the addition of firm-size and occupation dummies makes tenure no longer statistically significant. For men, tenure stays significant in this model. Looking across the models in Table 5, for men, tenure seems to matter more than years of experience and tenure matters even when we control for firm size, occupation and public sector. For women, tenure ceases to feature as a determinant of supplementary pension coverage once we control for firm size, occupation and public sector but years worked is still statistically significant. This contrasting pattern of results on experience and tenure for men and women points to different processes being at work. Referring back to the earlier discussion on theory, the apparently greater importance of tenure in the case of men could be related to staff retention objectives on the part of employers and the choice by certain men to remain with employers who offered pension benefits. 
Table 5: Probit model of supplementary pension coverage for men. Dependent variable is equal to 1 if the individual has income from a supplementary pension, zero otherwise

\begin{tabular}{|c|c|c|c|c|c|c|c|c|}
\hline & \multicolumn{2}{|l|}{1} & \multicolumn{2}{|c|}{2} & \multicolumn{2}{|c|}{3} & \multicolumn{2}{|l|}{4} \\
\hline & Marg. Eff. & t-value & Marg. Eff. & t-value & Marg. Eff. & t-value & Marg. Eff. & t-value \\
\hline Age & -0.00010 & -0.03 & -0.00045 & -0.15 & & & -0.00121 & -0.35 \\
\hline Number of children & 0.01048 & 1.26 & 0.00968 & 1.15 & & & 0.01187 & 1.32 \\
\hline Married & 0.09929 & 2.60 & 0.09707 & 2.54 & & & 0.08283 & 1.95 \\
\hline \multicolumn{9}{|l|}{$\begin{array}{l}\text { Education (reference - } \\
\text { none/primary) }\end{array}$} \\
\hline Secondary & 0.16123 & 4.47 & 0.15007 & 4.10 & & & 0.11646 & 2.73 \\
\hline Third level & 0.32117 & 8.05 & 0.31834 & 7.81 & & & 0.20394 & 3.42 \\
\hline Poor as child & 0.02572 & 0.64 & 0.03524 & 0.84 & & & 0.02452 & 0.56 \\
\hline Owns home & 0.15811 & 4.19 & 0.13163 & 3.41 & & & 0.11868 & 3.03 \\
\hline Years worked & 0.00220 & 0.13 & 0.00332 & 0.19 & & & 0.00142 & 0.07 \\
\hline Squared years worked & -0.00009 & -0.46 & -0.00008 & -0.42 & & & 0.00001 & 0.06 \\
\hline Tenure & & & 0.03413 & 6.85 & & & 0.02545 & 4.63 \\
\hline Squared tenure & & & -0.00059 & -6.43 & & & -0.00040 & -3.88 \\
\hline Health & 0.04244 & 2.70 & 0.04434 & 2.72 & & & 0.03091 & 1.72 \\
\hline \multicolumn{9}{|c|}{ Location (reference - Dublin) } \\
\hline Town & -0.18704 & -3.68 & -0.18969 & -3.65 & & & -0.19806 & -3.49 \\
\hline Rural & -0.32077 & -7.39 & -0.30193 & -6.58 & & & -0.18567 & -3.41 \\
\hline Part-time & & & & & -0.07263 & -0.89 & -0.00840 & -0.09 \\
\hline \multicolumn{9}{|l|}{ Firm size (reference - 1-5) } \\
\hline $6-15$ & & & & & 0.15922 & 2.94 & 0.17643 & 3.28 \\
\hline $16-24$ & & & & & 0.21456 & 3.66 & 0.23008 & 3.83 \\
\hline 25-199 & & & & & 0.31232 & 7.46 & 0.30170 & 6.88 \\
\hline $200-499$ & & & & & 0.32278 & 6.59 & 0.31067 & 6.31 \\
\hline $500+$ & & & & & 0.40216 & 10.38 & 0.37796 & 8.77 \\
\hline \multicolumn{9}{|l|}{$\begin{array}{l}\text { Occupation } \\
\text { (reference - unskilled) }\end{array}$} \\
\hline Professional & & & & & 0.30565 & 4.91 & 0.15517 & 1.63 \\
\hline Managerial & & & & & 0.41126 & 9.78 & 0.27751 & 4.61 \\
\hline Non-manual & & & & & 0.24848 & 3.94 & 0.10682 & 1.33 \\
\hline Skilled manual & & & & & 0.08302 & 1.35 & 0.01556 & 0.23 \\
\hline Semi-skilled & & & & & 0.18052 & 3.02 & 0.12265 & 1.81 \\
\hline Farmer & & & & & 0.04285 & 0.53 & -0.00091 & -0.01 \\
\hline Public sector & & & & & 0.34113 & 8.91 & 0.33569 & 8.64 \\
\hline No. of observations & \multicolumn{2}{|c|}{1,046} & \multicolumn{2}{|c|}{1,046} & \multicolumn{2}{|c|}{1,046} & \multicolumn{2}{|c|}{1,046} \\
\hline F-statistic & \multicolumn{2}{|c|}{$F(12,450)=15.69$} & \multicolumn{2}{|c|}{$F(14,488)=15.39$} & \multicolumn{2}{|c|}{$F(13,449)=21.76$} & \multicolumn{2}{|c|}{$F(27,435)=11.53$} \\
\hline
\end{tabular}


Table 6: Probit model of supplementary pension coverage for women. Dependent variable is equal to 1 if the individual has income from a supplementary pension, zero otherwise

\begin{tabular}{|c|c|c|c|c|c|c|c|c|}
\hline & \multicolumn{2}{|l|}{1} & \multicolumn{2}{|c|}{2} & \multicolumn{2}{|l|}{3} & \multicolumn{2}{|c|}{4} \\
\hline & Marg. Eff. & t-value & Marg. Eff. & t-value & Marg. Eff. & t-value & Marg. Eff. & t-value \\
\hline Age & 0.00525 & 1.38 & 0.00467 & 1.20 & & & 0.00639 & 1.61 \\
\hline Number of children & 0.01434 & 1.31 & 0.01122 & 1.01 & & & 0.02563 & 2.10 \\
\hline Married & -0.09936 & -2.09 & -0.09354 & -1.96 & & & -0.09722 & -1.91 \\
\hline \multicolumn{9}{|l|}{$\begin{array}{l}\text { Education (reference - } \\
\text { none/primary) }\end{array}$} \\
\hline Secondary & 0.11043 & 2.25 & 0.09889 & 2.01 & & & 0.03642 & 0.61 \\
\hline Third level & 0.39601 & 8.21 & 0.37782 & 7.55 & & & 0.18953 & 2.59 \\
\hline Poor as child & -0.01311 & -0.24 & 0.00864 & 0.15 & & & -0.00515 & -0.09 \\
\hline Owns home & 0.01443 & 0.29 & 0.02467 & 0.50 & & & 0.02447 & 0.47 \\
\hline Years worked & 0.02561 & 2.84 & 0.01647 & 1.79 & & & 0.01915 & 1.95 \\
\hline Squared years worked & -0.00034 & -2.54 & -0.00025 & -1.80 & & & -0.00026 & -1.82 \\
\hline Tenure & & & 0.02075 & 2.96 & & & 0.00909 & 1.13 \\
\hline Squared tenure & & & -0.00031 & -2.09 & & & -0.00007 & -0.44 \\
\hline Health & 0.03050 & 1.53 & 0.03460 & 1.75 & & & 0.02470 & 1.15 \\
\hline \multicolumn{9}{|c|}{ Location (reference - Dublin) } \\
\hline Town & -0.14352 & -2.77 & -0.14557 & -2.84 & & & -0.15488 & -2.65 \\
\hline Rural & -0.06345 & -1.19 & -0.06422 & -1.21 & & & -0.00351 & -0.06 \\
\hline Part-time & & & & & -0.02862 & -0.62 & -0.02197 & -0.43 \\
\hline \multicolumn{9}{|l|}{ Firm size (reference - 1-5) } \\
\hline $6-15$ & & & & & 0.12559 & 1.73 & 0.16299 & 1.99 \\
\hline $16-24$ & & & & & 0.13327 & 1.54 & 0.14975 & 1.52 \\
\hline 25-199 & & & & & 0.24166 & 3.41 & 0.26791 & 3.47 \\
\hline $200-499$ & & & & & 0.41402 & 4.74 & 0.42622 & 4.58 \\
\hline $500+$ & & & & & 0.47990 & 6.55 & 0.47824 & 5.83 \\
\hline \multicolumn{9}{|l|}{$\begin{array}{l}\text { Occupation } \\
\text { (reference - unskilled) }\end{array}$} \\
\hline Professional & & & & & 0.30571 & 1.77 & 0.12664 & 0.62 \\
\hline Managerial & & & & & 0.26945 & 3.59 & 0.17999 & 1.90 \\
\hline Non-manual & & & & & 0.16754 & 2.04 & 0.14681 & 1.55 \\
\hline Skilled manual & & & & & -0.03400 & -0.39 & -0.02122 & -0.21 \\
\hline Semi-skilled & & & & & 0.01053 & 0.12 & 0.01085 & 0.12 \\
\hline Farmer & & & & & 0.27778 & 1.64 & 0.02543 & 0.14 \\
\hline Public sector & & & & & 0.29613 & 6.03 & 0.27401 & 5.30 \\
\hline No. of observations & \multicolumn{2}{|c|}{618} & \multicolumn{2}{|c|}{618} & \multicolumn{2}{|c|}{618} & \multicolumn{2}{|c|}{618} \\
\hline F-statistic & \multicolumn{2}{|c|}{$F(12,353)=7.84$} & \multicolumn{2}{|c|}{$F(14,351)=7.52$} & \multicolumn{2}{|c|}{$F(13,352)=8.96$} & \multicolumn{2}{|c|}{$F(27,338)=6.17$} \\
\hline
\end{tabular}

Table 7: Simulated impact of a 10 per cent reduction in social welfare pensions

\begin{tabular}{|l|r|r|r|r|r|r|r|r|r|r|r|}
\hline & $\begin{array}{c}\text { 1st } \\
\text { Income } \\
\text { Decile }\end{array}$ & $\begin{array}{c}\text { 2nd } \\
\text { Income } \\
\text { Decile }\end{array}$ & $\begin{array}{c}\text { 3rd } \\
\text { Income } \\
\text { Decile }\end{array}$ & $\begin{array}{c}\text { 4th } \\
\text { Income } \\
\text { Decile }\end{array}$ & $\begin{array}{c}\text { 5th } \\
\text { Income } \\
\text { Decile }\end{array}$ & $\begin{array}{c}\text { 6th } \\
\text { Income } \\
\text { Decile }\end{array}$ & $\begin{array}{c}\text { 7th } \\
\text { Income } \\
\text { Decile }\end{array}$ & $\begin{array}{c}\text { 8th } \\
\text { Income } \\
\text { Decile }\end{array}$ & $\begin{array}{c}\text { 9th } \\
\text { Income } \\
\text { Decile }\end{array}$ & $\begin{array}{c}\text { 10th } \\
\text { Income } \\
\text { Decile }\end{array}$ & $\begin{array}{c}\text { Total } \\
\text { Mean income before }\end{array}$ \\
\hline Mean income after & 48.2 & 194.1 & 221.6 & 230.0 & 237.8 & 264.7 & 339.6 & 464.7 & 631.0 & $1,181.1$ & $\mathbf{3 4 3 . 4}$ \\
\hline Decrease in income (\%) & 5.6 & 178.4 & 200.0 & 207.4 & 215.5 & 243.1 & 319.0 & 444.5 & 614.6 & $1,163.8$ & $\mathbf{3 2 5 . 2}$ \\
\hline
\end{tabular}




\section{Conclusions and implications}

Trends in demographics that characterise the populations of most developed countries have instigated research and policy debate about the structure and the sustainability of pension systems and many have highlighted the importance of funded supplementary pension provision in sustaining adequate levels of income for retirees. Irish policymakers have also initiated plans for mandatory supplementary pension schemes for all employees and set targets for increased supplementary pension coverage rates. In order to examine how the Irish pension system provides for current retirees with relatively long working histories, this paper examines the levels and compositions of Irish retirees' pension incomes as well as the factors that affect the probability of a retired individual receiving income from a supplementary pension.

The findings can inform policies aiming to increase supplementary pension coverage among the current working population. The most consistent and statistically significant findings that hold for both men and women are that individuals with third level education, home-owners, Dublin residents, employees of large firms or the public sector and white-collar workers are more likely to have supplementary pension arrangements. Therefore, measures to promote pension coverage should target the segments of the labour force that include the self-employed, those working in small firms and those with non-continuous work patterns. Focusing measures on increasing supplementary pension coverage among women in particular could be optimal as women are disproportionally represented in the groups of workers with low earnings and non-continuous labour market participation patterns. While it might be argued that female participation has increased substantially in recent years, it should also be noted that age-specific participation rates are still lower for women. For example, for those aged 25-34, the most recent figures show the male participation rate to be 89.1 per cent compared to 77.4 per cent for women (Central Statistics Office, 2012).

The findings of this paper can advise public policies concerning both current and future retirees. As the first part of this paper reports, a significant share of current retirees relies on State welfare payments as their only source of income in retirement. Therefore, reducing the State welfare pension rates would negatively impact the incomes of a significant group of Irish retirees, and the effect would be highly regressive. As shown in Table 7, a simple simulation exercise shows that a reduction of 10 per cent in social welfare pensions would reduce incomes by 
almost 10 per cent in the $3 \mathrm{rd}$ and 4 th deciles $^{1}$ and by only 1.5 per cent in the top decile. While such a cut might ultimately be deemed necessary in the context of overall budgetary adjustment, any decision should factor in the distributional considerations as highlighted here.

${ }^{1}$ The lowest deciles will include people with no social welfare pensions and so these would be unaffected by any such cut. 


\section{References}

\section{References}

Barrientos, A. (1998a). "Pension reform, personal pensions and gender differences in pension coverage". World Development, 26(1), 125-137.

Barrientos, A. (1998b). Pension reform in Latin America. Aldershot, Ashgate.

Baroni, E. and O'Donoghue, C. (2009). Research Working Paper 2009/09: Poverty Impact of State Pension Reform on the Elderly: an analysis of reform proposals in the 2007 Irish Green Paper. Dublin: Combat Poverty Agency.

Central Statistics Office (2011). Survey on Income and Living Conditions (SILC): Thematic Report on the Elderly 2004 and 2009.

Central Statistics Office (2012). Quarterly National Household Survey, Q1 2012.

Department of Social and Family Affairs (2007). Green Paper on Pensions. Dublin: The Stationery Office.

Department of Social and Family Affairs (2010). National Pensions Framework. Dublin: The Stationery Office.

Department of Social Protection (2010). Rates of Payment 2010. Available from: http://www.welfare.ie/EN/Publications/sw19 $\quad$ 10/Documents/sw19 10.pdf [accessed 16 January 2012].

Dummann, K. (2008). "What determines supply and demand for occupational pensions in Germany?" Journal of Pension Economics and Finance, 7(2), 131-156.

European Commission (2012): The 2012 Ageing Report, Brussels: European Commission.

Eurostat. (2012) 1st January population by sex and 5-year age groups. Available from: http://appsso.eurostat.ec.europa.eu/nui/show.do?dataset=proj 10c2150p\&lang=en [accessed 20 February 2012]

Ghilarducci, T. (1992). Labor's Capital: The Economics and Politics of Private Pensions. London: MIT Press.

Holzmann, R., Packard, T. and Cuesta, J. (1999). Extending Coverage in Multi-pillar Pension Systems: Constraints and Hypotheses, Preliminary Evidence and Future Research Agendas. Social Protection (The World Bank) Discussion Paper no 0002. 
Hughes, G. and Nolan, B. (1999). "Competitive and Segmented Labour Markets and Exclusion from Retirement Income". ESRI Working Paper 108, Dublin: The Economic and Social Research Institute.

Layte, R., Fahey, T. and Whelan, C. (1999). Income, deprivation and well-being among older Irish people. Dublin: National Council on Ageing and Older People Report No. 55

Levine. P.B., Mitchell, O.S. and Phillips, J.W. (1999). "Worklife Determinants of Retirement Income Differentials between Men and Women". National Bureau of Economic Research Working Paper No. w7243.

Modigliani, F. and Brumberg, R. (1954). Utility analysis and the consumption function: an interpretation of cross-section data, in K. Kurihara (ed), Post Keynesian Economics (p. 388-436). New Brunswick: NJ Rutger University Press.

The Pensions Board (1998). Securing Retirement Income: National Pensions Policy Initiative: Report of the Pensions Board to the Minister for Social, Community and Family Affairs. Dublin: The Pensions Board.

World Bank (1994). Averting the old age crisis: policies to protect the old and promote growth. Word Bank Policy Research Report 13584. New York: Oxford University Press. 
Notes 
Notes 


\section{tilda}

hÉireann um Dhul in Aois

The Irish Longitudinal

Study on Ageing$$
\text { Study on Ageing }
$$ 